\title{
IMPLANTACJA ZARODKÓW UTWORZONYCH Z KOMÓREK ROZRODCZYCH SAMOTNYCH KOBIET - PROPOZYCJE PRZEPISÓW PRZEJŚCIOWYCH
}

\section{WSTĘP}

Dostęp do medycznie wspomaganej prokreacji (MAR) przez osoby samotne jest regulowany rozmaicie w poszczególnych systemach prawnych. W niektórych ustawodawstwach nie przewidziano dostępu samotnych kobiet do procedur MAR ${ }^{1}$. W innych państwach jest to dopuszczalne, ale zazwyczaj pod pewnymi warunkami, wynikającymi albo wprost z przepisów prawa, albo z praktyki klinik leczenia niepłodności². Problem ten rozstrzygany jest zgodnie z różnymi podstawami aksjologicznymi. Przyjęty w danym ustawodaw-

* Rafał Łukasiewicz, Uniwersytet Rzeszowski, rlukasiewicz@ur.edu.pl, https://orcid.org/0000-0003-4054-7492.

${ }^{1}$ Na przykład: w Austrii (zgodnie z § 2 (1) ustawy federalnej zmieniającej ustawę o medycynie reprodukcyjnej, kodeks cywilny, ustawę o inżynierii genetycznej i ustawę o funduszu IVF nowelizacja ustawy z 2015 r. o medycynie reprodukcyjnej - FMedRÄG 2015): „reprodukcja wspomagana medycznie jest dozwolona tylko w małżeństwie, zarejestrowanym związku partnerskim lub w związku partnerskim"; we Włoszech (zgodnie z art. 5 ust. 1 ustawy z 24 lutego 2004 r. nr 45 zasady medycznie wspomaganej prokreacji): „,bez uszczerbku dla postanowień artykułu 4 ustęp 1, pary osób dorosłych różnej płci, będące w związkach małżeńskich lub konkubinatach, w wieku potencjalnie rozrodczym, mogą uzyskać dostęp do technik wspomaganej medycznie prokreacji”, czy w Polsce. Szerzej: Tabela uzupełniająca nr SX do raportu ESHRE: Calhaz-Jorge et al. (2020): $1-15$.

${ }^{2}$ Na przykład: w Hiszpanii (zgodnie z art. 6 ust. 1 ustawy nr 14/2006 w sprawie technik wspomaganego rozrodu człowieka): „,biorcą lub użytkownikiem technik uregulowanych w ustawie może być każda kobieta, która ukończyła 18 lat i posiada pełną zdolność do czynności prawnych, pod warunkiem że wyrazi pisemną zgodę na ich użycie w sposób wolny, świadomy i wyraźny. Kobieta może być biorcą lub użytkownikiem technik uregulowanych w tej ustawie niezależnie od jej stanu cywilnego i orientacji seksualnej"); w Belgii (zgodnie z art. 2 pkt f) ustawy nr 2007023090 o wspomaganej medycznie prokreacji i przeznaczenia nadliczbowych embrionów i gamet): „autor planu rodzicielskiego to każda osoba, która podjęła decyzję o zostaniu rodzicem w drodze medycznie wspomaganej prokreacji, niezależnie od tego, czy jest ona przeprowadzana z jej własnych gamet lub embrionów”. Szerzej: Tabela uzupełniająca nr SX do raportu ESHRE (zob. przyp. 1). 
stwie model determinowany jest w głównej mierze uznaniem prymatu jednych praw nad innymi. Nie ulega bowiem wątpliwości, że przedstawione zagadnienie wiąże się w sposób oczywisty z koniecznością ważenia pewnych wartości, które często pozostają w kolizji ${ }^{3}$.

Ustawa o leczeniu niepłodności wyłączyła możliwość korzystania z medycznie wspomaganej prokreacji przez osoby samotne ${ }^{4}$. Obowiąujace regulacje prawne rozstrzygają również sytuację prawną samotnych kobiet, które jeszcze przed wejściem w życie wyżej wspomnianej ustawy uczestniczyły w procedurach medycznie wspomaganej prokreacji. Zarodek utworzony w tych procedurach nie może być implantowany do organizmu samotnej kobiety i w rezultacie powinien być po 20 latach od wejścia w życie ustawy przekazany do tzw. dawstwa zarodka.

Celem niniejszego artykułu jest próba przedstawienia rozwiązania normatywnego, które w racjonalny sposób stawałoby naprzeciw wskazanemu problemowi, łącząc ochronę interesów podmiotów zaangażowanych w procedury MAR ze spójnością przepisów ustawy o leczeniu niepłodności. W pierwszej części przedstawione zostaną uwagi krytyczne w stosunku do aktualnego stanu prawnego. Następnie uwaga zostanie poświęcona koncepcjom rozwiązania zarysowanych uprzednio problemów. Punktem wyjścia poszukiwań optymalnego unormowania będzie postanowienie Trybunału Konstytucyjnego z 18 kwietnia 2018 r. (S 2/18), w którym uznano, że prawo polskie powinno przewidywać możliwość wystapienia przez samotną kobietę do sądu opiekuńczego o zezwolenie na przeniesienie zarodka, który powstał przed wejściem w życie ustawy o leczeniu niepłodności ${ }^{5}$. W niniejszym artykule podjęta zostanie próba wskazania wad takiego rozwiąania. Jednocześnie przedstawiona zostanie konkurencyjna propozycja.

Poza zakresem analizy pozostaje przy tym ocena zasadności wydania postanowienia sygnalizacyjnego i nierozstrzygnięcia przed Trybunał Konstytucyjny sprawy z wniosku Rzecznika Praw Obywatelskich w sposób merytoryczny ${ }^{6}$. Ograniczone ramy artykułu nie pozwalają także na dostatecznie

${ }^{3}$ W tym kontekście dyskusje koncentrują się zazwyczaj wokół zasady dobra dziecka, prawa do poszanowania życia prywatnego i rodzinnego, zasady równego traktowania i niedyskryminacji czy prawa do autonomii prokreacyjnej. Szerzej Bączyk-Rozwadowska (1028): 78-95, 620-622.

${ }^{4}$ Ustawa z 25 czerwca 2015 r. o leczeniu niepłodności, t.jedn.: Dz. U. 2020, poz. 442 (dalej jako: u.l.n.).

${ }^{5}$ Postanowienie TK z 18 kwietnia 2018 r., S 2/18, OTK-A 2018, poz. 20.

${ }^{6} \mathrm{~W}$ zdaniu odrębnym do postanowienia TK z 18 kwietnia 2018 r., S 2/18, wskazano, że: „wydanie w niniejszej sprawie postanowienia sygnalizacyjnego nie było konieczne. Trybunał powinien był rozpoznać merytorycznie wniosek Rzecznika Praw Obywatelskich z 29 października 2015 r. (który spełniał ustawowe wymagania formalne) oraz wydać wyrok stwierdzający niekonstytucyjność zakwestionowanych przepisów w zakresie, w jakim dotyczą zarodków, które przed dniem wejścia w życie ustawy o leczeniu niepłodności zostały już utworzone z komórek rozrodczych kobiet niezamężnych lub niepozostających w stałym pożyciu i z komórek rozrodczych anonimowych dawców, i które przed tym terminem zostały przekazane do przechowania”. W dalszej części podkreślono, że: „na tle tych przepisów nie chodzi zatem o lukę (pominięcie legislacyjne), ani tym bardziej o zaniechanie ustawodawcze (w znaczeniu wynikającym z orzecznictwa Trybunału), lecz chodzi o jednoznaczne rozstrzygnięcie ustawodawcy, które powinno być ocenione przez Trybunał pod kątem zgodności z wzorcami konstytucyjnymi wskazanymi we wniosku”. Zob. też: 
dokładne ustosunkowanie się do kwestii dopuszczalności procedur medycznie wspomaganej prokreacji dla osób samotnych w innych przypadkach niż sytuacja, w której zarodki zostały już utworzone przed wejściem w życie ustawy o leczeniu niepłodności. Wobec tego pominięta zostanie analiza argumentów powoływanych w dyskusji na ten temat.

\section{ZARODKI UTWORZONE Z KOMÓREK ROZRODCZYCH KOBIET SAMOTNYCH A USTAWA O LECZENIU NIEPLODNOŚCI}

W okresie poprzedzającym wejście w życie ustawy o leczeniu niepłodności brak było szczegółowych regulacji normujacych tę problematykę. Ośrodki leczenia niepłodności niejednokrotnie działały zgodnie z zasadą quod lege non prohibitum, licitum est (czego prawo nie zakazuje, to jest to dozwolone). Dopiero ustawa o leczeniu niepłodności zakazała niektórych występujących w praktyce procedur, w tym medycznie wspomaganej prokreacji dostępnej dla osób samotnych. Jak wskazują przeprowadzone w okresie od stycznia 2015 do marca 2015 r. badania, tylko pięć ośrodków leczenia niepłodności w Polsce zadeklarowało niewykonywanie świadczeń na rzecz pacjentów samotnych lub pozostających w związkach jednopłciowych (na trzydzieści pięć, w których przeprowadzono monitoring bezpośredni) ${ }^{7}$. Pokazuje to, że procedury te były powszechnie dostępne dla kobiet samotnych.

Kluczowy dla określenia pozycji kobiet samotnych, z których komórek rozrodczych utworzono zarodki, jest art. 97 u.l.n.; zgodnie z nim zarodki utworzone i przechowywane przed dniem wejścia w życie ustawy sa przekazywane do dawstwa zarodka: 1) po upływie 20 lat od dnia wejścia w życie ustawy, chyba że wcześniej zostaną przekazane przez dawców zarodka do dawstwa zarodka; 2) w przypadku zaistnienia okoliczności, o których mowa w art. 21 ust. 3 pkt 2 u.l.n. Wykładnia powyższego przepisu powinna odbywać się przy uwzględnieniu, że ustawa o leczeniu niepłodności ogranicza zakres podmiotów, które mogą uczestniczyć w procedurach medycznie wspomaganej prokreacji jedynie do małżonków oraz osób odmiennej płci, które pozostają we wspólnym pożyciu.

Powyższe przepisy nie tylko jednoznacznie przesądzają o tym, że zarodki utworzone z komórek rozrodczych samotnej kobiety nie mogą być przeniesione do jej organizmu, ale również prowadzą do potraktowania jej jak dawcy komórek rozrodczych wbrew jej woli ${ }^{8}$. Zarodek utworzony z komórek rozrodczych samotnej kobiety nie może być przeniesiony do jej organizmu, a zatem ex lege zostanie przekazany do dawstwa po 20 latach od wejścia w życie ustawy o leczeniu niepłodności ${ }^{9}$. Aktualna regulacja może prowadzić wobec tego

wniosek RPO z 29 października 2015 r., VII.501.139.2015.KM (dalej jako: Wniosek RPO); postanowienie TK z 18 kwietnia 2018 r., K 50/16, OTK-A 2018, poz. 19.

${ }^{7}$ Krawczak, Damska (2015): 39.

${ }^{8}$ Wniosek RPO: 11.

${ }_{9}$ Radkowska-Walkowicz (2016): 129. Samotna kobieta może podjąć próbę doprowadzenia do implantacji zarodka w ten sposób, że znajdzie mężczyznę, który dokończy razem z nią procedurę 
do urodzenia dziecka genetycznego samotnej kobiety w innej rodzinie bez jej zgody, a nawet wiedzy, mimo że to ona chciałaby urodzić dziecko i być w świetle prawa jego rodzicem. Takie ujęcie jest dyskusyjne, w szczególności z punktu widzenia realizacji zasady dobra dziecka: skoro dziecko może urodzić jego matka genetyczna, która chce je wychować, a alternatywa jest urodzenie tego dziecka w rodzinie, z którą dziecko nie jest genetycznie spokrewnione, to czy powinno się odmawiać dziecku prawa do wychowania przez genetyczną matkę jedynie w imię wychowania $\mathrm{w}$ pełnej rodzinie?

Wydaje się, że wskazówką przy odpowiedzi na to pytanie może być treść art. 7 in fine Konwencji o prawach dziecka, zgodnie z którym dziecko, jeżeli jest to możliwe, ma prawo do poznania swoich rodziców i pozostania pod ich opieką ${ }^{10}$. Wskazaną alternatywę (wychowanie przez samotną matkę genetyczna albo wychowanie przez rodzinę pełna, ale niespokrewniona) należałoby rozstrzygnać na korzyść pierwszej z możliwości. Skoro ustawie o leczeniu niepłodności przyświecała idea ochrony zarodków oraz ochrony dobra dziecka urodzonego w rezultacie przeprowadzonych procedur MAR, to w konsekwencji trudno nie dostrzec, że aktualne regulacje prawne pozbawiaja dziecko prawa do wychowania we własnej rodzinie ${ }^{11}$. Podkreślić przy tym należy, że wniosek ten nie musi oznaczać de lege ferenda aprobaty dostępu samotnych kobiet do MAR. Zakaz korzystania z medycznie wspomaganej prokreacji przez osoby samotne może być argumentowany ochrona dobra dziecka, tj. uniknięciu sytuacji, w której dziecko będzie miało tylko jednego prawnego rodzica. Chodzi przy tym o rozstrzygnięcie, czy powinno się rozpoczynać procedurę w sytuacji, w której z góry wiadomo, że dziecko nie będzie miało ojca. Natomiast w ana-

dawstwa heterologicznego, występując jako osoba pozostająca z nią we wspólnym pożyciu (niezgodnie ze stanem faktycznym). Należy krytycznie odnieść się do tego typu zachowania. Przede wszystkim musiałoby dojść do uznania ojcostwa z art. $75^{1}$ k.r.o. W związku z tym, że konieczne do tego oświadczenia mogą być złożone tylko przez osoby pozostające we wspólnym pożyciu, doszłoby do wprowadzenia w błąd kierownika urzędu stanu cywilnego. Poza tym mężczyzna musiałby liczyć się z konsekwencjami prawnymi złożonych oświadczeń, np. w zakresie dziedziczenia czy alimentacji.

${ }^{10}$ Konwencja o prawach dziecka, przyjęta przez Zgromadzenie Ogólne Narodów Zjednoczonych dnia 20 listopada 1989 r., Dz. U. 1991, Nr 120, poz. 526.

${ }^{11}$ Zob. uzasadnienie projektu ustawy o leczeniu niepłodności, m.in.: „Intencją projektodawcy nie jest bowiem zwiększenie dostępności do przedmiotowych świadczeń, ale stworzenie ram prawnych do ich wykonywania, a tym samym zapewnienie właściwego postępowania z komórkami rozrodczymi i zarodkami, bezpieczeństwa dawców i biorczyń komórek rozrodczych i zarodków oraz dzieci, które urodzą się w wyniku zastosowania procedury medycznie wspomaganej prokreacji. [...] Celem projektowanych w tym zakresie przepisów jest zapewnienie wysokiej jakości i bezpieczeństwa procedury, bezpieczeństwa dawców i biorczyń, jak również samych komórek rozrodczych i zarodków, a także - co bardzo istotne - dzieci, które urodzą się w wyniku zastosowania procedury medycznie wspomaganej prokreacji”. Ochrona każdego zarodka zdolnego do prawidłowego rozwoju oraz dobra dziecka urodzonego w rezultacie MAR stanowiły zatem ratio legis przepisów ustawy o leczeniu niepłodności. Spójność przepisów prawa wymaga wobec tego, aby wnioski de lege ferenda korespondowały z pozostała częścią przyjętych przepisów prawnych z zakresu leczenia niepłodności. Równocześnie należy pamiętać, że nie wszystkie systemy prawne gwarantują ochronę wszystkich zarodków zdolnych do prawidłowego rozwoju, np. w Danii zostaja one zniszczone, jeżeli nie zostaną zastosowane w terminie 5 lat, a w Estonii, jeżeli nie zostana zastosowane w terminie 7 lat. Krasnowolski et al. (2015): 9-10. 
lizowanych w niniejszym artykule przypadkach problem dotyczy tego, w jaki sposób należy zakończyć procedurę już rozpoczęta. W rozważanych stanach faktycznych zarodek już istnieje. Przy obowiązującym w Polsce zakazie niszczenia zarodków zdolnych do prawidłowego rozwoju (art. 23 ust. 3 u.l.n.) należy - co już kilkukrotnie podkreślono - zdecydować, czy właściwsze z punktu widzenia realizacji zasady dobra dziecka jest dokończenie procedury przez genetyczna, ale samotną matkę, czy dawstwo zarodka innym osobom, które nie sa spokrewnione z dzieckiem. Zasada dobra dziecka, która może przemawiać za brakiem dostępu do procedur MAR przez osoby samotne, może równocześnie przemawiać za zakończeniem takich procedur z udziałem samotnej kobiety (implantacji zarodka do jej organizmu). Nawet przy przyjęciu, że dostęp do MAR przez osoby samotne może naruszać dobro dziecka w ten sposób, że z natury rzeczy nie będzie ono wychowywać się w pełnej rodzinie (i dlatego nie powinny powstawać zarodki na potrzeby procedury prowadzonej z udziałem osoby samotnej), nie można tracić z pola widzenia przedstawionych wyżej negatywnych skutków, jakie mogą wynikać z zakazu implantacji już utworzonego zarodka do organizmu samotnej kobiety (wychowanie przez rodzinę niegenetyczna, podczas gdy matka genetyczna dąży do urodzenia i wychowania dziecka).

W analizowanej sytuacji chodzi o przypadki, gdy zarodki są już utworzone. Wskazana wyżej alternatywa powinna być rozstrzygana wyłącznie z punktu widzenia realizacji dobra dziecka. W tym miejscu warto odnieść się do często przedstawianego argumentu o analogii między dopuszczalnością przysposobienia singularnego a koniecznością dopuszczenia MAR dla osób samotnych ${ }^{12}$. Wydaje się, że zbyt daleko idące jest stawianie znaku równości między tymi sytuacjami. W pierwszym przypadku chodzi bowiem o dziecko, które zostało już urodzone i poszukuje się dla niego rodziny, w drugim zaś - dopiero o utworzenie zarodka po to, aby dziecko urodziło się w określonej rodzinie ${ }^{13}$. Można jednak bronić poglądu, że analizowana w niniejszej publikacji sytuacja jest pod pewnymi względami bliska przysposobieniu singularnemu, gdyż dotyczy zarodków, które już zostały utworzone. W doktrynie prawa dostrzeżono pewne podobieństwo między przysposobieniem a dawstwem zarodków ${ }^{14}$. Wobec tego, że prawo polskie nie dopuszcza niszczenia zarodków, należy odpowiedzieć na pytanie, czy zgodne z dobrem dziecka jest urodzenie go przez samotna, ale genetyczną matkę, czy urodzenie w pełnej rodzinie, która nie jest z nim spokrewniona. Bardziej przekonujace jest pierwsze rozwiązanie, które wymusza zmianę ustawy o leczeniu niepłodności w ten sposób, aby możliwe było przeniesienie do organizmu samotnej kobiety zarodków utworzonych przed wejściem w życie ustawy.

Odrębnie należy odnieść się do wskazanego w art. 97 pkt. 1 u.l.n. dwudziestoletniego terminu przechowywania zarodków, który liczy się - co warto pod-

${ }^{12}$ M.in. Piechocki (1983): 68; Krzekowska (1988): 105-106.

${ }^{13}$ Podobnie w dyskusji na temat analogii między przysposobieniem a sztuczną inseminacja samotnej kobiety: Safjan (1990): 216-217.

${ }^{14}$ Haberko (2014): 3-15. 
kreślić - nie od dnia powstania zarodków, ale od dnia wejścia w życie ustawy o leczeniu niepłodności ${ }^{15}$. Nie jest wobec tego wykluczone, że zarodek będzie przechowywany dłużej niż dwadzieścia lat, a później przekazany do dawstwa zarodków. Urodzenie dziecka z zarodka zamrożonego przez dwadzieścia lat i dłużej nie jest zjawiskiem powszechnie występującym ${ }^{16}$. Ustawa o leczeniu niepłodności wprowadziła powyższy termin oraz konstrukcję dawstwa zarodków z mocy prawa po to, aby uniknać niszczenia zarodków. Gdyby przyjać, że istnieje ryzyko, że zarodki przechowywane przez 20 lat nie będą zdolne do prawidłowego rozwoju, wówczas wskazana wyżej dyskusja na temat zalet i wad zakazu implantacji zarodków do organizmu samotnych kobiet przenosiłaby się na inną płaszczyznę ${ }^{17}$. Alternatywę między wychowaniem dziecka przez samotną matkę genetyczną albo wychowaniem przez rodzinę pełna, ale niespokrewniona, należałoby zastapić inną alternatywą: implantacja zarodka samotnej kobiecie albo prawdopodobieństwo doprowadzenia zarodka do stanu uniemożliwiającego prawidłowy rozwój. Z drugiej jednak strony praktyka medyczna pokazuje, że urodzenie dzieci z zarodków zamrożonych przez kilkanaście lat zaczyna być coraz częstsze ${ }^{18}$. Odnotowano także przypadki narodzin dzieci z zarodków zamrożonych ponad 20 lat.

W kontekście analizowanej problematyki nie można także stracić z pola widzenia faktu, że procedury medycznie wspomaganej prokreacji były świadczone na rzecz samotnych kobiet na podstawie umów cywilnoprawnych, które były zawierane zgodnie z wówczas obowiąującymi przepisami prawa. Nawet przyjęcie poglądu, że umowy te były sprzeczne z zasadami współżycia społecznego, a wobec tego są nieważne, nie zmienia faktu, że wskutek tych procedur powstały zarodki i należy rozstrzygnąć, jaki ma być ich dalszy los. Wyłączenie możliwości implantacji zarodków osobom samotnym doprowadziło do opisywanych w mediach przypadków przenoszenia takich zarodków do ośrodków zagranicznych ${ }^{19}$. Zjawisko cross-borded reproductive care zyskuje w ostatnich latach na popularności, co związane jest z istotnymi różnicami w modelach ustawowych dotyczacych medycznie wspomaganej prokreacji ${ }^{20}$. Do najbardziej kluczowych

15 Haberko (2016): 435.

${ }_{16}$ Aktualnie najdłużej zamrożonym zarodkiem, którego implantacja zakończyła się urodzeniem dziecka, jest zarodek zamrożony 25 lat. Szerzej: <https://www.huffingtonpost.co.uk/entry/ tina-gibson-frozen-embryo_n_5a39a151e4b06d1621b04a90> [dostęp: 2.11.2020].

$17 \mathrm{~W}$ niektórych systemach prawnych posłużono się podobną konstrukcja, termin przekazania zarodków do dawstwa jest jednak krótszy, np. w Portugalii (zgodnie z art. 25 ust. 1 ustawy nr 32/2006 Prokreacja medycznie wspomagana): „zarodki, które zgodnie z postanowieniami poprzedniego artykułu nie muszą być przenoszone, muszą zostać poddane kriokonserwacji, a beneficjenci zobowiązują się do ich wykorzystania w nowym procesie transferu zarodków w ciagu maksymalnie trzech lat. $\mathrm{Na}$ mocy zaś art. 25 ust. 2 tej ustawy: „po upływie trzech lat zarodki mogą być oddane innej parze, której wskazania medyczne wskazują na niepłodność, przy czym fakty rozstrzygające podlegają rejestracji”.

18 Szerzej: Papis et al. (2013): 971 i cytowana tam literatura.

$19<$ https://www.prawo.pl/zdrowie/kliniki-leczenia-nieplodnosci-przenosza-zarodki-za-granice,244955.html> [dostęp: 2.11.2020]; <https://wiadomosci.dziennik.pl/wydarzenia/artykuly/519058, skutki-uboczne-nowych-przepisow-o-in-vitro-samotne-kobiety-przenosza-swoje-zarodki-za-granice.html> [dostęp: 2.11.2020].

20 Szerzej m.in: Hudson et al. (2011): 673-685; Shenfield et al. (2010): 1361-1368. 
przyczyn korzystania z MAR w państwie innym niż państwo pochodzenia biorców jest między innymi dostęp do medycznie wspomaganej prokreacji dla osób samotnych oraz związków jednopłciowych. W analizowanym stanie faktycznym nie chodzi jednak o typowy przypadek transgranicznego korzystania z medycznie wspomaganej prokreacji, w którym osoby samotne jadą do innego kraju, aby rozpoczać procedury zakazane w Polsce. Mowa tutaj o przypadkach, w których osoby samotne rozpoczęły procedurę w Polsce wówczas, gdy nie było to zakazane, a brak właściwie ujętych przepisów przejściowych uniemożliwia im dokończenie procedury w kraju. Oznacza to, że obywatele polscy, którzy legalnie uczestniczyli w procedurach in vitro, zostali niejako zmuszeni do kontunuowania ich za granica.

\section{POSTANOWIENIE TRYBUNALU KONSTYTUCYJNEGO Z 18 KWIETNIA 2018 ROKU A ROZWIĄZANIA KONKURENCYJNE}

Aprobująco należy odnieść się do dostrzeżonej przez Trybunał Konstytucyjny konieczności zmian w prawie, które umożliwiałyby samotnym kobietom implantacje zarodków utworzonych z ich komórek jajowych w poprzednim stanie prawnym. Przedstawiona wyżej argumentacja pokazuje, że kwestia ta wymaga reakcji ustawodawcy nie tylko ze względu na interes kobiety, ale przede wszystkim ze względu na interes dziecka, które urodzi się w konsekwencji implantowania zarodka.

Postanowienie TK z 18 kwietnia 2018 r. (S 2/18) jest konsekwencją wniosku RPO o stwierdzenie niezgodności art. 20 ust. 1 pkt 2 oraz art. 21 ust. 1 pkt 3 w zw. z art. 78 i 97 ustawy z 25 czerwca 2015 r. o leczeniu niepłodności, w zakresie, w jakim maja zastosowanie także do kobiet niepozostających w związku małżeńskim albo we wspólnym pożyciu z mężczyzna, które zdeponowały zarodki powstałe z ich komórki rozrodczej i komórki anonimowego dawcy przed dniem wejścia w życie tej ustawy, z art. 2 w zw. z art. 47 Konstytucji RP. Choć postanowieniem z 18 kwietnia 2018 r. (K 50/16) umorzono postępowanie, to jednak uznano za zasadne wydanie postanowienia sygnalizacyjnego. Trybunał dostrzegł konieczność wprowadzenia sądowej kontroli zezwalania samotnym kobietom na przeniesienie zarodków powstałych przed wejściem w życie ustawy o leczeniu niepłodności w stanach faktycznych mieszczących się w ramach dawstwa innego niż partnerskie.

Zaproponowane przez TK rozwiązanie polegajace na zezwoleniu sądu opiekuńczego na przeniesienie zarodków do organizmu samotnej kobiety jest oparte na konstrukcji analogicznej do art. 21 ust. 2 u.l.n., zgodnie z którym w przypadku braku zgody męża lub dawcy komórek rozrodczych pobranych w celu dawstwa partnerskiego, z których utworzono zarodek, na przeniesienie zarodka, zezwolenie na przeniesienie wydaje sąd opiekuńczy ${ }^{21}$. W przepisie tym chodzi o sytuację, gdy brak zgody męża lub partnera uniemożliwia im-

21 Szerzej: Haberko (2016): 148-151. 
plantację zarodka. Sąd opiekuńczy rozstrzyga kolizję interesów, biorąc pod uwagę pewne, nieokreślone bliżej w ustawie o leczeniu niepłodności, kryteria. W zaproponowanym przez TK rozwiązaniu rola sądu opiekuńczego nie sprowadzałaby się do rozstrzygnięcia sporu między kobietą a jej mężem lub partnerem, ale do ustalenia, czy powinno dojść do rodzicielstwa samotnej kobiety. Tutaj również pojawiają się wątpliwości, jakie kryteria powinien wziąć pod uwagę sąd opiekuńczy²2.

Konstrukcja ta przypomina znany niektórym systemom prawnym wymóg weryfikacji zasadności skorzystania z MAR przez samotną kobietę, przy uwzględnieniu różnych kryteriów ${ }^{23}$. Ocenia się przy tym między innymi predyspozycje matki genetycznej do wypełniania ról rodzicielskich oraz analizuje zgodność z dobrem dziecka sytuacji, w której nie będzie ono mieć prawnego ojca. Różnica polega jednak na tym, że w obcych systemach prawnych ocena taka dokonywana jest przed powstaniem zarodka, a w świetle zaproponowanego przez TK rozwiązania miałoby to następować w odniesieniu do zarodków, które już istnieja. Konstrukcja taka wydaje się dalece dyskusyjna. Posłużenie się nią oznacza bowiem, że sąd opiekuńczy oceniałby matkę genetyczna, biorąc pod uwage jej kwalifikacje osobiste, podobnie jak w odniesieniu do kandydatów do przysposobienia dziecka, a więc rodziców niegenetycznych. Jeżeli sąd opiekuńczy uznałby, że samotna matka nie spełnia tych kryteriów, wówczas zarodek byłby przekazany do dawstwa. Z kolei osoby, które korzystają z dawstwa zarodka w Polsce, nie są badane z punktu widzenia ich kwalifikacji osobistych $^{24}$. Wobec tego doszłoby do tego, że sąd opiekuńczy badałby, czy matka genetyczna będzie „dobra matka”, a gdyby stwierdził, że tak nie jest, dziecko trafiałoby do tzw. adopcji zarodków przez parę, co do której takie wymogi nie są stawiane.

Mając na uwadze powyższe, należy stwierdzić, że zaproponowaną przez TK propozycję zmiany prawa, która została zasygnalizowana Sejmowi i Senatowi, należy ocenić krytycznie. Wobec tego uzasadnione jest zaproponowanie konkurencyjnych rozwiązań. Można przyjąć, że rozstrzygnięcie analizowanej kwestii mogłoby nastapić przez zastosowanie jednego z dwóch modeli.

W pierwszym z nich należałoby wprowadzić przepis, zgodnie z którym kobiety mogłyby zastosować zarodki w terminie 20 lat od wejścia w życie ustawy o leczeniu niepłodności, ewentualnie od dnia, w którym zarodki zostały przekazane do banku komórek rozrodczych i zarodków w celu ich przechowywania, co stanowiłoby rozwiązanie analogiczne od konstrukcji unormowanej w art. 21 ust. 3 pkt 1 u.l.n. Aktualne pozostaja przy tym uwagi dotyczące ryzyka długiego przechowywania zarodków oraz dyskusyjnego charakteru konstrukcji dawstwa zarodka z mocy prawa.

${ }^{22}$ Podobne rozwiązanie było już zgłaszane de lege ferenda $\mathrm{w}$ polskiej literaturze w odniesieniu do korzystania z medycznie wspomaganej prokreacji przez samotne kobiety: Piechocki (1983): 68; Krzekowska (1988): 105-106; Radwański (1985): 182. Krytycznie: Safjan (1990): 218. Autor podawał pod wątpliwość, jakie kryteria powinien w takich przypadkach brać pod uwagę sąd wyrażający zgodę na zabieg.

${ }^{23}$ Szerzej: Baczzyk-Rozwadowska (2018): 86-95.

${ }^{24}$ Haberko (2014): 10. 
Drugim sposobem na rozwiązanie problemu zarodków utworzonych przed wejściem w życie ustawy o leczeniu niepłodności z komórek rozrodczych kobiet samotnych byłoby wprowadzenie regulacji, zgodnie z która przepisów ustawy nie stosuje się w odniesieniu do nich w określonym zakresie. Takie ujęcie mogłoby jednak być słusznie skrytykowane jako sprzeczne z założeniami ustawy o leczeniu niepłodności i prowadzące do niespójności przepisów. Brak zastosowania terminu miałby tę zaletę, że nie dochodziłoby do dawstwa zarodków z mocy prawa, a więc bez wiedzy i woli samotnych kobiet. Należy bowiem pamiętać, że osoby decydujace się na medycznie wspomaganą prokreację w aktualnym porządku prawnym muszą liczyć się ze świadomościa, że ich zarodki mogą być przekazane do dawstwa. Natomiast samotne kobiety, które uczestniczyły w tych procedurach przed obowiązywaniem ustawy o leczeniu niepłodności, nie wyrażały zgody na uczestniczenie w nich na zasadach ustawy, a zatem także na przekazanie zarodków do dawstwa w razie ich niezastosowania. Z drugiej jednak strony powyższe rozwiązanie prowadziłoby do tego, że zarodki musiałyby być przechowywane bezterminowo, co wobec zakazu ich niszczenia niewątpliwie kłóciłoby się z przyjętą przez ustawodawcę podstawa aksjologiczną ustawy.

Powyższe wahania w zakresie zalet oraz wad potencjalnych rozwiąań świadczą o niewątpliwych trudnościach wskazania konstrukcji przepisu przejściowego, który w optymalny sposób rozwiązywałby analizowany w niniejszym artykule problem. Nie ulega wątpliwości, że samotne kobiety powinny mieć prawo do implantacji zarodków utworzonych w okresie poprzedzającym obowiąywanie ustawy o leczeniu niepłodności z ich komórek rozrodczych. W szczególności przemawia za tym relatywnie krótka, trzymiesięczna vacatio legis ustawy o leczeniu niepłodności (art. 100 u.l.n.). Jednocześnie zaproponowanie przepisu przejściowego, który z jednej strony pozwoliłby na uszanowanie tego prawa, z drugiej zaś - byłby spójny z pozostałymi regulacjami ustawy o leczeniu niepłodności, nie należy do zadań łatwych.

Wydaje się, że rozwiązaniem, które przynajmniej w ograniczonym zakresie godzi sprzeczne interesy pojawiajace się na tle badanej kwestii, byłoby wprowadzenie dwudziestoletniego terminu na zastosowanie komórek rozrodczych przez samotne kobiety, liczonego od dnia wejścia w życie ustawy o leczeniu niepłodności. Pozwalałoby to na zastosowanie zarodków przez kobiety, które nie zdążyły tego zrobić w trzymiesięcznym terminie vacatio legis. Mogło to nastapić z różnych przyczyn, często niezależnych od decyzji kobiet (np. w razie podjęcia leczenia onkologicznego). Z daleko idącym prawdopodobieństwem można stwierdzić, że kobiety, które chcą implantować zarodki utworzone z ich komórek rozrodczych oraz nasienia anonimowego dawcy, zrobiłyby to niedługo po wprowadzeniu takiego przepisu przejściowego. Nie można przy tym tracić z pola widzenia okoliczności, że powyższe ujęcie przepisu przejściowego nie pozwalałoby całkowicie uniknąć dawstwa zarodków z mocy prawa, gdyż zazwyczaj zarodków jest kilka i nie można wykluczyć, że kobieta nie dążyłaby do implantacji ich wszystkich, choć teoretycznie miałaby taką możliwość. Wobec powyższego zjawisko dawstwa zarodków z mocy prawa w istotnym zakresie mogłoby mieć mniejszą skalę, część zarodków zostałaby bowiem implantowa- 
na samotnym kobietom, a nie intencyjnym matkom, które nie są z nim spokrewnione. W związku z tym art. 97 pkt 1 u.l.n. powinien być skonstruowany w taki sposób, aby wyjątkiem od przekazania zarodków do dawstwa z mocy prawa nie było wyłącznie wyrażenie zgody na dawstwo, ale także przeniesienie do organizmu biorczyni zarodka w sytuacji, gdy biorczynią jest samotna kobieta, która przed wejściem w życie ustawy uczestniczyła w procedurze dawstwa heterologicznego.

\section{WNIOSKI}

Brak możliwości implantacji zarodka utworzonego przed wejściem w życie ustawy o leczeniu niepłodności z komórek rozrodczych samotnej kobiety powinien być oceniany nie tylko z perspektywy jej praw, ale przede wszystkim przy uwzględnieniu zasady dobra dziecka. U podstaw ustawy o leczeniu niepłodności leżało przeświadczenie o konieczności ochrony zarodków, czego wyrazem jest - po pierwsze - zakaz ich niszczenia, po drugie - konstrukcja dawstwa zarodków z mocy prawa, po trzecie zaś - wprowadzenie sankcji karnej w przypadku, gdyby doszło do zniszczenia zarodków zdolnych do prawidłowego rozwoju. Jednocześnie ustawodawca, wprowadzając dwudziestoletni termin, po którym zarodki zostaną przekazane do dawstwa, doprowadza do sytuacji, w której trudno jednoznacznie stwierdzić, czy będą one mogły zostać skutecznie zastosowane i czy w rezultacie tego będzie mogło urodzić się dziecko. Niemniej jednak, nawet przy założeniu, że dziecko może się w takim wypadku urodzić, przekazanie zarodka do dawstwa osobom trzecim, niespokrewnionym z dzieckiem powinno budzić sprzeciw wobec możliwości urodzenia i wychowania dziecka przez samotna, ale genetyczną matkę.

Zaproponowana przez TK konstrukcja zezwolenia sądu na implantację zarodka samotnej kobiecie jest dalece dyskusyjna. Watpliwości może budzić w szczególności to, jakimi kryteriami powinien kierować się sąd opiekuńczy przy tego typu rozstrzygnięciach. Można przypuszczać, że samotna kobieta podlegałaby ocenie z punktu widzenia jej kwalifikacji osobistych, jak dzieje się w niektórych państwach, które dopuszczają warunkowo MAR dla osób samotnych. W związku z tym pozycja samotnej kobiety jest nieproporcjonalna w stosunku do pozycji osób, na rzecz których miałby być przekazany zarodek w razie braku wydania zezwolenia przez sąd opiekuńczy, gdyż wobec nich nie stawia się żadnych wymagań z zakresu kwalifikacji osobistych.

Zaproponowane $\mathrm{w}$ niniejszym artykule rozwiązanie nie jest z pewnościa w pełni zadowalające dla wszystkich zabierających głos w dyskusji nad kształtem rozwiązań prawnych z zakresu leczenia niepłodności. Pozwala jednak na możliwość implantacji zarodków, które powstały przed wejściem w życie ustawy o leczeniu niepłodności, do organizmów samotnych kobiet, które uczestniczyły w procedurach MAR. Równocześnie rozwiązaniu temu trudno odmówić spójności z założeniami ustawy o leczeniu niepłodności. Z jednej strony pozwala ono na uniknięcie niszczenia zarodków, na co niewątpliwie położono nacisk, 
formułując przepisy badanej ustawy, z drugiej jednak - umożliwia samotnym kobietom dokończenie procedur medycznie wspomaganej prokreacji, w których zastosowano ich komórki rozrodcze. Zaprezentowana propozycja nie rozwiąuje jednak całkowicie problemu dawstwa zarodków z mocy prawa, gdyż pozostałe zarodki, których samotne kobiety nie zastosują w procedurach leczenia niepłodności, będą po dwudziestu latach przekazane do dawstwa wbrew ich woli.

Bączyk-Rozwadowska, K. (2018). Prokreacja medycznie wspomagana. Studium z dziedziny prawa. Toruń.

Calhaz-Jorge, C., De Geyter, Ch., Kupka M.S., Wyns, C., Mocanu E., Motrenko, T., Scaravelli, G., Smeenk, J., Vidakovic, S., Goossens, V. (2020). Survey on ART and IUI: legislation, regulation, funding and registries in European countries: The European IVF-monitoring Consortium (EIM) for the European Society of Human Reproduction and Embryology (ESHRE). Human Reproduction Open 1: 1-15.

Haberko, J. (2014). Zagrożenia dla instytucji przysposobienia wobec projektu rozwiązań legislacyjnych w zakresie leczenia niepłodności. Forum Prawnicze 4: 3-15.

Haberko, J. (2016). Ustawa o leczeniu niepłodności. Komentarz. Warszawa.

Hudson, N., Culley, L., Blyth, E., Norton, W., Rapport, F., Pacey, A. (2011). Cross-border reproductive care: a review of the literature. Reproductive BioMedicine Online 22: 673-685.

Krzekowska, K. (1988). Inseminatio artificialis a sytuacja prawna dziecka. Państwo i Prawo 43(6): 101-109.

Krasnowolski, A., Dragan, A., Korzeniowska-Linkowska, D.M., Stawicka, A., Woronowicz, S. (2015). Przepisy prawne dotyczące zapłodnienia pozaustrojowego obowiązujące w wybranych krajach. Warszawa.

Krawczak, A., Damska, A. (2015). Bocian sprawdza kliniki. Pierwszy pacjencki monitoring polskich ośrodków leczenia niepłodności. <http://www.nasz-bocian.pl/pliki/monitoring_pacjencki_NB_2015.pdf> [dostęp: 31.10.2020].

Papis, K., Lewandowski, P., Wolski, J.K., Kozioł, K. (2013). Dzieci urodzone z zarodków przechowywanych w stanie zamrożenia przez 10 lat. Analiza 5 przypadków. Ginekologia Polska 84: 970-973.

Piechocki, S. (1983). Aspekty prawne sztucznego zapłodnienia i implantacji embrionu. Nowe Prawo 6.

Radkowska-Walkowicz, M. (2016). „To wielkie zwycięstwo polskiej wolności”? Nowa ustawa regulująca leczenie metodą in vitro w Polsce w perspektywie antropologicznej. Prawo i Medycyna 62(1): $123-140$.

Radwański, Z. (1985). Stanowisko prawne dziecka w następstwie sztucznego unasiennienia matki. Studia Iuridica Silesiana 5.

Safjan, M. (1990). Prawo wobec ingerencji w naturę ludzkiej prokreacji. Warszawa.

Shenfield, D., Mouzon, J. de, Pennings G., Ferraretti, A.P., Nyboe Andersen, A., de Wert, G., Goossens, V. (2010). Cross border reproductive care in six European countries. Human Reproduction 25(6): 1361-1368.

\section{IMPLANTATION OF EMBRYOS CREATED USING \\ A SINGLE WOMAN'S REPRODUCTIVE CELLS: \\ PROPOSALS FOR TRANSITIONAL PROVISIONS}

\section{Sum mary}

According to the Polish Infertility Treatment Act, single women do not have access to medically assisted reproduction (MAR). Nevertheless, many single women had taken part in third-party reproduction before the Infertility Treatment Act came into effect. Under the current legal regulations, they are not entitled to have their embryos, which were created from their oocytes and 
anonymous donors' semen, implanted. Given that Polish Law prohibits destroying embryos, the embryos will be stored for 20 years and after this time they will be donated to other couples without the single woman's consent or knowledge. This means that a donor-conceived child will be brought up by non-genetic parents instead of their genetic mother, who wanted to give birth to a child and be responsible for him or her. The aim of this article is to analyse the risks associated with the above problem. The Polish Constitutional Tribunal's proposal of 18 April 2018 (S 2/18) recommends the consent of the family court to embryo implantation in the cases of single women who took part in third party-reproduction using MAR before it became illegal. In this article I present some weaknesses of this solution and present another proposal which gives a chance to protect the involved parties' interests, and which is consistent with the current legal regulations.

Keywords: medically assisted reproduction; infertility treatment; single mothers; third-party reproduction; in vitro 